\title{
EFEKTIFITASSTRETCHING EXERCISE DAN PERNAFASAN YOGA TERHADAP REGULASI TEKANAN DARAH DAN KUALITAS HIDUP KLIEN ESRD YANG MENJALANI HEMODIALISIS DI RUMKITAL DR. RAMELAN SURABAYA
}

\author{
Nur Muji Astuti ${ }^{1}$, I Ketut Sudiana ${ }^{2}$, Joni Haryanto ${ }^{3}$
}

1. Mahasiswa Program Magister Keperawatan, Universitas Airlangga, email: nurmujiastuti04@gmail.com

2. Departemen Ilmu Patologi Anatomi, Fakultas Kedokteran Universitas Airlangga

3. Departemen Keperawatan Gerontik, Fakultas Keperawatan Universitas Airlangga

\begin{abstract}
Hypertension intradialytic can affect the quality of life and quality of life can affect hypertension too. An area of concern to nurses is related to non-pharmacological treatment to prevent the occurrence of intradialitic hypertension and improved quality of life. One of them is with stretching exercise and yoga breathing. This research used quasi experimental pre post control group design design, sample size was 28 ESRD clients intradialysis in Dr. Rumkital. Ramelan Surabaya. Sampling technique used purposive sampling. Variables in this study were stretching exercise, yoga breathing, stretching exercise modification and yoga breathing, systolic blood pressure, diastolic blood pressure, and quality of life. Data collection using mercury sygmomanometer, and KDQOL SF 1.3 questionnaire. Data were analyzed using paired t test and multiple linear regression. The results of this study showed that the most effective intervention for lowering blood pressure $27,143 \mathrm{mmHg}$ is a combination of stretching exercise and respiratory yoga, whereas the most effective yoga breathing improves the quality of life 5,143. ESRD clients intradialysis are expected to remain active in applying stretching exercises and breathing yoga during hemodialysis, and for nurses is expected to increase client motivation as well as arrange a daily program and actively involved in applying stretching exercise and yoga breathing.
\end{abstract}

\section{Key Word: Stretching Exercise, Yoga Breathing, Blood pressure, Quality Of Life}

\section{Abstrak:}

Hipertensi intradialitik dan kualitas hidup memiliki hubungan timbal balik, hipertensi dapat mempengaruhi kualitas hidup begitu pun sebaliknya kualitas hidup dapat mempengaruhi hipertensi. Upaya non farmakologis untuk mengatasi adalah dengan stretching exercise dan pranayama yoga. Penelitian ini menggunakan desain quasi eksperimental pre post control group design, sampel sejumlah 28 klien ESRD yang menjalani hemodialisi di ruang hemodialisis Rumkital Dr. Ramelan Surabaya. Tekhnik sampling menggunakan purposive sampling. Variabel di dalam penelitian ini adalah stretching exercise, pernafasan yoga, modifikasi stretching exercise dan pernafasan yoga, tekanan darah sistolik, tekanan darah diastolik, dan kualitas hidup.pengumpulan data menggunkan modul, sygmomanometer air raksa, dan kuesioner KDQOL SF 1.3. data dianalisa menggunakan paired $t$ test dan regresi linier berganda. Hasil penelitian ini menunjukkan bahwa intervensi yang paling efektif untuk menurunkan tekanan darah 27,143 $\mathrm{mmHg}$ adalah kombinasi antara stretching exercise dan pernafasan yoga, sedangkan pernafasan yoga paling efektif meningkatkan kualitas hidup 5,143. Klien ESRD yang menjalani hemodialisis diharapkan tetap aktif mengaplikasikan stretching 
exercise dan pernafasan yoga (pranayama) selama menjalani hemodialisis, dan untuk perawat ruangan diharapkan meningkatkan motivasi klien serta menyusun program harian dan terlibat aktif dalam mengaplikasikan stretching exercise dan pernafasan yoga

Kata Kunci: Stretching exercise, pernafasan yoga, tekanan darah, kualitas hidup

\section{PENDAHULUAN}

Komplikasi hemodialisis salah satunya adalah peningkatan tekanan darah. Tekanan darah biasanya menurun dengan ultrafiltrasi dialisis pada sebagian besar klien, namun $10-15 \%$ klien yang menjalani hemodialisis mengalami peningkatan tekanan darah (Sulistyaningsih 2011). Dilaporkan Sekitar 5-15\% dari klien yang menjalani HD reguler tekanan darahnya justru meningkat saat HD. Kondisi ini disebut hipertensi intradialitik (HID) atau intradialytic hypertension(Agarwal 2011). Menurut penelitian yang dilakukan oleh (Armiyati 2015)didapatkan hasil bahwa $70 \%$ klien mengalami hipertensi intradialisis. Suatu area yang menjadi perhatian perawat adalah hal yang berhubungan dengan penanganan non farmakologis untuk mencegah terjadinya hipertensi intradialitik dan peningkatan kualitas hidup, beberapa penelitian menunjukkan bahwa pendekatan non farmakologis dapat dilakukan yaitu meliputi tekhnik mengurangi stres, penurunan berat badan, pembatasan alkohol, natrium, dan tembakau, olahraga atau latihan yang berefek meningkatkan lipoprotein densitas tinggi, dan relaksasi. Latihan fisik peregangan atau stretchingexercise dipercaya meningkatkan fungsi fisik dan mental pada klien dengan dialisa, bahkan dapat meningkatkan kualitas hidupnya (Painter et al. 2000). (Kaur et al, 2016)dalam penelitiannya menyebutkan bahwa dalam waktu satu minggu dilakukan stretching exercise pada klien dialisis dapat meningkatkan skor kualitas hidup sebesar 0,25. Mekanisme latihan fisik peregangan atau stretching exercise meningkatkan relaksasi yaitu dengan menurunkan aktifitas saraf simpatis dan meningkatkan aktifitas saraf parasimpatis sehingga terjadi vasodilatasi diameter arteriol (Hermanto 2014).Pranayama yoga adalah jembatan antara pikiran dan hal-hal fisik antara tubuh dan roh (Sherman et al. 2010). Yoga dapat meningkatkan adekuasi klien ESRD dengan hemodialisis (Tayyebi et al. 2012). Beberapa hasil penelitian menunjukkan hasil bahwa yoga dapat memberikan efek relaksasi sehingga menstimulus hipotalamus untuk menurunkan ACTH dimana diikuti penurunan glukokortikoid dan kortisol. Berdasarkan latar belakang masalah tingginya kejadian hipertensi intradialitik dan penurunan kualitas hidup klien hemodialisis maka penulis tertarik untuk melakukan penelitian pengaruh stretching exercise dan pernafasan yoga (pranayama) terhadap regulasi tekanan darah dan kualitas hidup klien end stage renal disease (ESRD) yang menjalani hemodialisis.

\section{METODE}

Penelitian ini menggunakan quasi eksperimen dengan metode pre test- post test control group design. Desain ini digunakan untuk membandingkan pengaruh stretching exercise, pernafasan yoga (pranayama), serta modifikasi antara stretching exercise dan pernafasan yoga (pranayama) terhadap regulasi tekanan darah, dan kualitas hidup pada klien ESRD yang menjalani hemodialisis.Populasi dalam penelitian ini adalah semua klien ESRD yang melakukan terapi hemodialisis di ruang hemodialisis Rumkital Dr. Ramelan Surabaya pada pada bulan MeiJuni 2017. Tekhnik pengambilan sampel dalam penelitian ini dilakukan dengan metode purposive samplingsejumlah 7 responden di tiap kelompok. Total 28 responden. 
Etik penelitian pada penelitian ini diberikan oleh komite etik Rumkital Dr. Ramelan Surabaya.

Instrumen

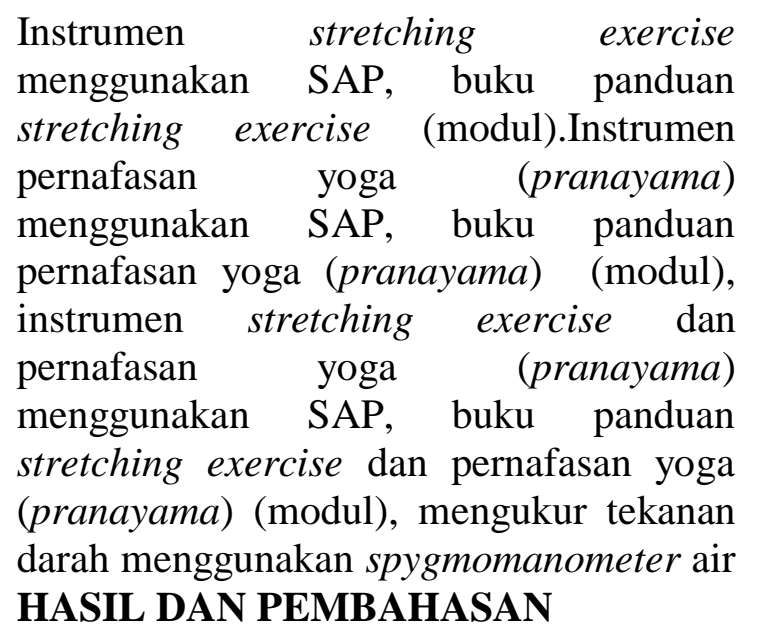

raksa yang telah dilakukan kalibrasi dan lembar observasi, kualitas hidup pasien penyakit ginjal kronik yang menjalani hemodialisis diukur dengan menggunakan kuesioner Kidney Disease Quality Of Life Short Form 1.3 (KDQOL-SF 1.3) yang telah diterjemahkan ke dalam bahasa Indonesia.

\section{LOKASI DAN WAKTU PENELITIAN}

Penelitian ini dilaksanakan di Rumah Sakit TNI Angkatan Laut dr. Ramelan Surabaya di ruang Hemodialisis, terdiri dari 24 bed beserta alat hemodialisis nya. Ruangan nyaman disertai ruang tunggu. Pengumpulan data dilaksanakan bulan 2 Mei hingga 31 Mei 2017

1. Tekanan darah sistolik

Tabel 5.2. Ringkasan hasil uji beda rata-rata antara kelompok

\begin{tabular}{|c|c|c|c|c|c|c|c|}
\hline \multicolumn{2}{|c|}{ Kelompok } & Rata-rata & St dev. & Normalitas & $\begin{array}{l}\text { Statistik } \\
\text { hitung }\end{array}$ & Signifikansi & Keterangan \\
\hline \multirow{2}{*}{ K1 } & Pre & 170.00 & 33.665 & 0.200 & \multirow[b]{2}{*}{$\mathrm{t}=3.464$} & \multirow{2}{*}{0.013} & \multirow{2}{*}{ Berbeda signifikan } \\
\hline & Post & 150.00 & 30.000 & 0.503 & & & \\
\hline \multirow{2}{*}{$\mathrm{K} 2$} & Pre & 148.57 & 13.452 & 0.873 & \multirow{2}{*}{$\mathrm{t}=-1.146$} & \multirow{2}{*}{0.296} & \multirow{2}{*}{$\begin{array}{c}\text { Tidak berbeda } \\
\text { signifikan }\end{array}$} \\
\hline & Post & 158.57 & 22.678 & 0.086 & & & \\
\hline \multirow{2}{*}{$\mathrm{K} 3$} & Pre & 150.00 & 24.495 & 0.753 & \multirow{2}{*}{$\mathrm{t}=2.517$} & \multirow{2}{*}{0.045} & \multirow{2}{*}{ Berbeda signifikan } \\
\hline & Post & 131.43 & 12.150 & 0.147 & & & \\
\hline \multirow{2}{*}{$\mathrm{K} 4$} & Pre & 138.57 & 12.150 & 0.237 & \multirow{2}{*}{$\mathrm{t}=-4.583$} & \multirow{2}{*}{0.004} & \multirow{2}{*}{ Berbeda signifikan } \\
\hline & Post & 158.57 & 10.690 & 0.294 & & & \\
\hline
\end{tabular}

2. Tekanan darah diastolik

Tabel 5.3. Ringkasan hasil uji beda rata-rata antar kelompok

\begin{tabular}{|c|c|c|c|c|c|c|c|}
\hline \multicolumn{2}{|c|}{ Kelompok } & Rata-rata & St dev. & Normalitas & $\begin{array}{l}\text { statistik } \\
\text { hitung }\end{array}$ & Signifikansi & Keterangan \\
\hline \multirow{2}{*}{ K1 } & Pre & 92.86 & 13.801 & 0.099 & \multirow{2}{*}{$Z=-2.121$} & \multirow{2}{*}{0.034} & \multirow{2}{*}{ Berbeda signifikan } \\
\hline & Post & 84.29 & 7.868 & 0.001 & & & \\
\hline \multirow{2}{*}{ K2 } & Pre & 88.57 & 3.780 & 0.000 & \multirow{2}{*}{$Z=-0.378$} & \multirow{2}{*}{0.705} & \multirow{2}{*}{$\begin{array}{l}\text { Tidak berbeda } \\
\text { signifikan }\end{array}$} \\
\hline & Post & 88.57 & 14.639 & 0.002 & & & \\
\hline \multirow{2}{*}{ K3 } & Pre & 81.43 & 3.780 & 0.000 & \multirow{2}{*}{$Z=-0.577$} & \multirow{2}{*}{0.564} & Tidak berbeda \\
\hline & Post & 82.86 & 4.880 & 0.000 & & & signifikan \\
\hline \multirow{2}{*}{ K4 } & Pre & 82.86 & 4.880 & 0.000 & \multirow{2}{*}{$Z=-1.000$} & \multirow{2}{*}{0.317} & Tidak berbeda \\
\hline & Post & 85.71 & 7.868 & 0.020 & & & signifikan \\
\hline
\end{tabular}

3. Kualitas Hidup

Tabel 5.4. Ringkasan hasil uji beda rata-rata kualitas hidup antar kelompok

\begin{tabular}{|c|c|c|c|c|c|c|c|}
\hline \multicolumn{2}{|c|}{ Kelompok } & Rata-rata & St dev. & Normalitas & $\begin{array}{l}\text { statistik } \\
\text { hitung }\end{array}$ & Signifikansi & Keterangan \\
\hline \multirow{2}{*}{$\mathrm{K} 1$} & Pre & 40.89 & 6.259 & 0.481 & \multirow{2}{*}{$t=-0.606$} & \multirow{2}{*}{0.567} & \multirow{2}{*}{$\begin{array}{c}\text { Tidak berbeda } \\
\text { signifikan }\end{array}$} \\
\hline & Post & 42.00 & 6.998 & 0.296 & & & \\
\hline \multirow{2}{*}{$\mathrm{K} 2$} & Pre & 44.75 & 5.132 & 0.628 & \multirow{2}{*}{$\mathrm{t}=-2.592$} & \multirow{2}{*}{0.041} & \multirow{2}{*}{ Berbeda signifikan } \\
\hline & Post & 47.85 & 4.901 & 0.702 & & & \\
\hline \multirow{2}{*}{ K3 } & Pre & 42.29 & 7.365 & 0.738 & \multirow{2}{*}{$\mathrm{t}=-2.117$} & \multirow{2}{*}{0.079} & \multirow{2}{*}{$\begin{array}{l}\text { Tidak berbeda } \\
\text { signifikan }\end{array}$} \\
\hline & Post & 44.08 & 7.688 & 0.619 & & & \\
\hline
\end{tabular}




\begin{tabular}{llllllll}
\hline \multirow{2}{*}{ K4 } & Pre & 45.29 & 7.033 & 0.247 & \multirow{2}{*}{0.015} & \multirow{2}{*}{ Berbeda signifikan } \\
& Post & 42.40 & 5.738 & 0.463 & & \\
\hline
\end{tabular}

Efektifitas intervensi terhadap tekanan darah dan kualitas hidup

1. Variabel tekanan darah sistolik Untuk mengetahui seberapa besar efektifitas intervensi terhadap tekanan darah sistolik, selanjutnya dilakukan analisis regresi yang berguna untuk mendapatkan pengaruh variabel-variabel bebas (K1 (stretching exercise), K2 (pernafasan yoga), K3 (kombinasi), dan K4 (kontrol)) terhadap variabel Y (tekanan darah sistolik post).

Berdasarkan hasil pengolahan data dengan menggunakan software SPSS 22 didapatkan model regresi sebagai berikut: $\mathrm{Y}=158,571-8,571 *$ stretching0,000*yoga-27,143*kombinasi

Keterangan:

$\mathrm{Y}=$ tekanan darah sistolik

Apabila yoga dan kombinasi konstan, dan stretching dilakukan sesuai prosedur maka akan menurunkan tekanan darah sistolik 8,57 mmHg. Apabila stretching dan kombinasi konstan dan yoga dilakukan sesuai prosedur maka akan menurunkan tekanan darah sistolik 0,000 $\mathrm{mmHg}$. Apabila stretching dan yoga konstan, dan kombinasi dilakukan sesuai prosedur maka akan menurunkan tekanan darah sistolik 27,143 mmHg.

2. Variabel tekanan darah diastolik

Pada variabel tekanan darah diastolik tidak dilakukan uji regresi linier karena data bersifat tidak normal.

3. Variabel kualitas hidup

Untuk mengetahui seberapa besar efektifitas intervensi terhadap kualitas hidup, selanjutnya dilakukan analisis regresi yang berguna untuk mendapatkan pengaruh variabel-variabel bebas (K1 (stretching exercise), K2 (pernafasan yoga), K3 (kombinasi), dan K4 (kontrol)) terhadap variabel $\mathrm{Y}$ (tekanan darah diastolik post).

Berdasarkan hasil pengolahan data dengan menggunakan software SPSS 22 didapatkan model regresi sebagai berikut:
$\mathrm{Y}$ $=$ $42,571-$ $0,714 *$ stretching $+5,143 *$ yoga $+1,286 * \mathrm{kom}$ binasi

Keterangan:

$\mathrm{Y}=$ kualitas hidup

Apabila yoga dan kombinasi konstan, dan stretchingdilakukan sesuai prosedur maka akan menurunkan kualitas hidup 0,714. Apabila stretching dan kombinasi konstan dan yoga dilakukan sesuai prosedur maka akan menaikkan kualitas hidup 5,143. Apabila stretching dan yoga konstan, dan kombinasi dilakukan sesuai prosedur maka akan meningkatkan kualitas hidup 1,286.

Tekanan darah

Rata-rata angka penurunan tekanan darah sistolik tertinggi ada pada kelompok stretching exercise, rata-rata peningkatan tekanan darah sistolik ada pada kelompok kontrol. Penurunan tekanan darah diastolik tertinggi pada kelompok stretching exercise, dan rata-rata angka penurunan diastolik terendah pada kelompok yoga dan kontrol masing-masing sebesar 1.43. Dalam keadaan relaks, tubuh melalui otak akan memproduksi endorphrin yang berfungsi sebagai analgesik alami tubuh dan dapat meredakan rasa nyeri (keluhankeluhan fisik). sistem saraf parasimpatetis yang aktif berfungsi untuk menurunkan tekanan darah (Poppen, 1998). Relaksasi adalah suatu prosedur dan teknik yang bertujuan untuk mengurangi ketegangan dan kecemasan, dengan cara melatih pasien agar mampu dengan sengaja untuk membuat relaksasi otot-otot tubuh setiap saat, sesuai dengan keinginan.

Penelitian yang dilakukan oleh Ross dalam Purnawarman, menjelaskan bahwa latihan fisik pada klien gangguan vaskuler dapat berfungsi ganda yaitu meningkatkan ekspresi protein e NOS yang dapat berlangsung selama beberapa jam dan meningkatkan fosforilasi eNOS dalam beberapa menit sehingga 
meningkatkan produksi NO vaskular dimana sangat berperan penting terhadap fungsi endotelium pada klien dengan gangguan pembuluh darah. Antara proporsi fosforilsasi eNOS dan perubahan endothelium tergantung pada aliran pembuluh darah yang di rangsang oleh latihan fisik yang dilakukan, hal ini konsisten dengan hipotesis bahwa peningkatan ekspresi protein NOS dan fosforilasi berperan penting terhadap perubahan fungsi endotelium pada pasien dengan penyakit pembuluh darah.Stretching exercise juga dapat menurunkan level kelelahan pada klien yang menjalani hemodialisis, hal ini dapat dijelaskan bahwa dengan latihan maka akan meningkatkan peredaran darah ke otot dan juga memperluas permukaan kapiler yang menghasilkan aliran urea dan toksin lebih besar ke alat dialiser, selain itu stretching exercise dapat memperbaiki fungsi fisik klien (Thejaswi et al. 2016).

Peneliti berpendapat bahwa latihan yang intensif disertai dengan perasaan yang rileks akan meningkatkan fungsi dari jantung sehingga klien dapat rileks dan menurunkan tekanan darah sistolik dan diastolik.

Kelompok pernafasan yoga didapatkan hasil terdapat peningkatan ratarata angka sistolik yang tidak signifikan dan tidak terdapat perbedaan tekanan diastolik yang signifikan antara sebelum dan setelah perlakuan. Yoga memiliki efek relaksasi yang dapat meningkatkan sirkulasi darah ke seluruh tubuh, sirkulasi darah yang lancar mengindikasikan kerja jantung yang baik (Oktavia, Indriati, and Supriyadi 2012). Ruangan yang tenang berventilasi baik dan nyaman merupakan hal yang dibutuhkan dalam melakukan yoga (Worby, 2011). Lingkungan sangat berpengaruh terhadap tekanan darah dan tingkat stres sesuai penelitian tentang pengaruh intensitas kebisingan terhadap tekanan darah dan tingkat stres kerja dilakukan oleh Ardiansyah, Salim, \& Susihono bahwa tekanan darah mengalami kenaikan sebelum dan sesudah bekerja masing-masing sebesar $2.39 \mathrm{mmHg}$ untuk sistolik dan $3.53 \mathrm{mmHg}$ untuk diastolik. Tingkat stres kerja mengalami kenaikan sebesar 5.33 satuan. Hal ini sesuai dengan kondisi lingkungan saat dilakukan hemodialisis dimana tidak menutup kemungkinan pada saat hemodialisis berlangsung mesin mengalami kemacetan dan alarm berbunyi sehingga akan mengurangi konsentrasi serta meningkatkan rasa panik, dimana akan sangat berpengaruh terhadap intervensi pernafasan yoga yang membutuhkan ketenangan. Peneliti berpendapat bahwa suasana yang tenang, nyaman serta konsentrasi yang tinggi akan mendukung terciptanya suasana relaks sehingga dapat menurunkan aktifitas saraf simpatis dan akan menurunkan tekanan darah.

Pada kelompok modifikasi stretching exercise dan pernafasan yoga didapatkan hasil yang signifikan terhadap tekanan darah sistolik dan tidak berbeda signifikan terhadap penurunan tekanan darah diastolik. Hal ini sejalan dengan penelitian yang dilakukan Moniaga \& Pangemanan, tentang latihan peregangan yang dilakukan pada lansia memberikan hasil penurunan tekanan darah sistolik yang bermakna, sedangkan tekanan darah diastolik mengalami kenaikan dan tidak menunjukan perbedaan bermakna tapi masih dalam batas normal. Penurunan tahanan perifer dapat jelaskan dari dua mekanisme yaitu terjadinya perubahan pada aktivitas sistem saraf simpatik dan respon vaskular setelah berolahrga.Pertama, secara neurohumoral menurunnya aktivitas sistem saraf simpatik pada pembuluh darah perifer sebagai petunjuk terjadi penurunan tekanan darah.Kedua, respon vaskular mempunyai peranan penting pada penurunan tekanan darah setelah berolahraga.Exercise pada klien hemodialisis dapat mengurangi konsumsi obat-obatan antihipertensi (Capitanini et al. 2008) 
Kualitas hidup

Rata-rata angka peningkatan kualitas hidup tertinggi pada kelompok yoga dan rata-rata angka penurunan kualitas hidup terendah pada kelompok kontrol. Salah satu terapi yang direkomendasikan untuk ESRD adalah hemodialisis (Hartanti and Kidney 2016), namun meskipun hemodialisis berkala mencegah kematian akibat uremia rendahnya harapan hidup klien masih menjadi suatu permasalahan (Zyga and Sarafis 2009). Kualitas hidup yang baik menjadi salah satu indikator keberhasilan terapi hemodialisis yang dilakukan (Mailani 2015).

Hasil dalam penelitian ini menyebutkan kualitas hidup tertinggi ada pada kelompok yoga, hal ini dapat dijelaskan bahwa pernafasan yoga dapat meningkatkan kualitas hidup seseorang seperti yang dijelaskan oleh (Kinasih 2010) setiap manusia mempunyai cara untuk meningkatkan kualitas hidup, dan salah satunya dengan yoga.Pranayama dalam yoga meningkatkan pernafasan dan menurunkan detak jantung.Berdasar penelitian tersebut disimpulkan bahwa syaraf otonom yang aktif adalah syaraf parasimpatis yang berfungsi memperlambat detak jantung dan mengatur sekresi kelenjar adrenalin.Aktivitas syaraf simpatis dapat menurunkan tingkat kecemasan pada responden. Intervensi yang dapat menurunkan kecemasan dan depresi akan meningkatkan kualitas hidup klien ( $\mathrm{Li}$ et al. 2016). Latihan yoga khususnya pranayama atau pernafasan yoga dapat membuat individu mengidentifikasi pemikiran negatif yang jauh berkembang dalam pikiran mereka (Segal, 2002). Saat menarik dan menghembuskan nafas udara masuk dalam tubuh membawa oksigen yang berfungsi sebagai bahan bakar untuk mengaktifkan sel di dalam tubuh (Kinasih 2010). Kualitas hidup yang baik menjadi salah satu indikator keberhasilan terapi hemodialisis yang dilakukan. Pada kelompok stretching exercise didapatkan hasil yang tidak berbeda secara signifikan. Hal ini dapat dijelaskan bahwa pentingnya motivasi dan tingkat kelelahan klien akan sangat mempengaruhi kualitas hidup seseorang, dimana tingkat stres pada kelompok ini lebih banyak berada pada stres sedang. Hal ini sejalan dengan (Henson et al. 2016) yang menyebutkan hambatan yang dihadapi individu dengan penyakit ginjal kronis pada perawatan hemodialisis meliputi peningkatan kadar kelelahan, penurunan motivasi, dan ketidakmampuan untuk menjadwalkan latihan akan mempengaruhi kualitas hidup seseorang. Peneliti berpendapat bahwa meskipun tindakan stretching exercise dapat meningkatkan fungsi fisik dan mental klien namun ada beberapa faktor penting yang perlu dinilai yakni motivasi, tingkat stres dan depresi, dan kondisi fisik klien yang melakukan latihan.

Pada kelompok kontrol didapatkan nilai kualitas hidup terendah hal ini dapat dijelaskan bahwa terapi hemodialisis membutuhkan waktu yang lama, memiliki komplikasi dan membutuhkan kepatuhan klien, hal ini akan memberikan stresor fisiologis dan psikologis bagi klien yang kemudian akan mempengaruhi kualitas hidup klien (Sulistyarini 2013). Pada kelompok modifikasi stretching exercise dan pernafasan yoga didapatkan nilai kualitas hidup yang kurang signifikan antara sebelum dan sesudah perlakuan.Kondisi konsentrasi juga berpengaruh terhadap kualitas seseorang, dimana pada kelompok modifikasi diberikan gabungan dua intervensi sekaligus yang tidak menutup kemungkinan bahwa terjadinya penurunan konsentrasi untuk melakukan hal tersebut secara bersamaan. Seperti diungkapkan oleh (Septia 2014) bahwa konsentrasi dapat mempengaruhi hasil keterampilan menyimak. Peneliti berpendapat bahwa adanya faktor koping individu, kondisi lingkungan serta daya konsentrasi seseorang akan mempengaruhi suatu intervensi. 


\section{SIMPULAN}

\section{Simpulan}

1. Stretching exercise merupakan intervensi komplementer yang dapat digunakan untuk menurunkan tekanan darah sistolik dan diastolik pada klien ESRD yang menjalani hemodialisis

2. Pernafasan yoga (pranayama) yang dilakukan rutin dapat meningkatkan kualitas hidup klien ESRD yang menjalani hemodialisis

3. Kombinasi stretching exercise dan pernafasan yoga merupakan intervensi yang paling efektif dalam menurunkan tekanan darah dan pernafasan yoga merupakan intervensi yang paling efektif meningkatkan kualitas hidup klien ESRD yang menjalani hemodialisis

\section{Saran}

Stretching exercise dan pernafasan yoga bermanfaat untuk meningkatkan relaksasi klien, sehingga diharapkan hasil penelitian ini sebagai acuan untuk menyusun standar operasional prosedur ruangan dan bagi peneliti selanjutnya Peneliti selanjutnya diharapkan dapat meneliti lebih lanjut dengan mengukur tekanan darah secara time series sehingga didapatkan efektifitas waktu terhadap intervensi stretching exercise dan pernafasan yoga (pranayama).

\section{DAFTAR PUSTAKA}

Agarwal, Rajiv. 2011. "Interdialytic Hypertension-An Update." Advances in Chronic Kidney Disease 18(1): 11-16.

Ardiansyah, Muhamad Rian, Ja Salim, and Wahyu Susihono. 2013. "Pengaruh Intensitas Kebisingan Terhadap Tekanan Darah Dan Tingkat Stres Kerja." Jurnal Tekhnik Industri 1(1): 7-12.

Armiyati, Yunie. 2015. "Hipotensi Dan Hipertensi Intradialisis Pada Hemodialisis Di RS PKU Muhammadiyah Yogyakarta." (July):
$1-9$.

Capitanini, Alessandro et al. 2008. "Effects of Exercise Training on Exercise Aerobic Capacity and Quality of Life in Hemodialysis Patients." Journal Of Nephrology 21: 738-43.

Hartanti, Rita Dwi, and National Kidney. 2016. "Exercise Intradialisis Meningkatkan Nilai URR Pasien Gagal Ginjal Kronik Dengan Hemodialisis." In The 3rd University Research Colloquium, , 533-41.

Henson, Angela et al. 2016. "Intradialytic Exercise: A Feasibility Study Intradialytic Exercise: A Feasibility Study." Renal Society of AUstralia Journal 6(1): 11-15.

Hermanto, Jeri. 2014. "Pengaruh Pemberian Meditasi Terhadap Penurunan Tekanan Darah Pada Lansia Dengan Hipertensi Di Unit Sosial Rehabilitasi Pucang Gading Semarang."

Kinasih, Arum Sukma. 2010. "Pengaruh Latihan Yoga Terhadap Kualitas Hidup Pasien Hemodialisis." 18(1): $1-12$.

Li, Yi-nan et al. 2016. "Association between Quality of Life and Anxiety, Depression , Physical Activity and Physical Performance in Maintenance Hemodialysis Patients." Chronic Diseases and Translational Medicine 2(2): 110-19. http://dx.doi.org/10.1016/j.cdtm.2016 .09 .004 .

Mailani, Fitri. 2015. "Kualitas Hidup Pasien Penyakit Ginjal Kronik Yang Menjalani Hemodialisis: Systematic Review." Ners Jurnal Keperawatan 11(1): 1-8.

Moniaga, Victor, and Damajanty H C Pangemanan. 2013. "Pengaruh Senam Bugar Lansia Terhadap Tekanan Darah Penderita Hipertensi Di Bplu Senja Cerah Paniki Bawah 2." E biomedik Journal 1(1): 785-89. Oktavia, Devi, P A Indriati, and Supriyadi. 
2012. "Pengaruh Latihan Yoga Terhadap Penurunan Tekanan Darah Pada Lanjut Usia ( Lansia ) Di Panti Wreda Pengayoman ' Pelkris , Semarang." Journal Keperawatan STIKES Telogorejo: $1-8$.

Painter, Patricia et al. 2000. "Physical Functioning and Health-Related Quality-of-Life Changes with Exercise Training in Hemodialysis Patients." American Journal of Kidney Diseases 35(3): 482-92.

Purnawarman, Adi. 2014. "Pengaruh Latihan Fisik Terhadap Fungsi Endotel." Jurnal Kesehatan Syiah Kuala 14(2): 109-18.

Septia, Syifa. 2014. "Hubungan Antara Daya Konsentrasi Dan Keterampilan Menyimak Mahasiswa BAhasa Jerman UPI.” : 1-16.

Sherman, Karen J et al. 2010. "Study Protocol Comparison of Yoga versus Stretching for Chronic Low Back Pain : Protocol for the Yoga Exercise Self-Care ( YES ) Trial." Trialsjurnal: 1-17.

Sulistyaningsih, Dwi Retno. 2011. "Efektivitas Latihan Fisik Selama Hemodialisis Terhadap Peningkatan Kekuatan Otot Pasien Penyakit Ginjal Kronik Di Rumah Sakit Umum Daerah Kota Semarang." Universitas Indonesia.

Sulistyarini, Indahria. 2013. "Terapi Relaksasi Untuk Menurunkan Tekanan Darah Dan Meningkatkan Kualitas Hidup Penderita Hipertensi." Jurnal Psikologi 40(1): 28-38.

Tayyebi, Ali et al. 2012. "Study of the Effect of Hatha Yoga Exercises on Dialysis Adequacy." Iranian Journal Of Critical Care Nursing 4(4): 18390.

Thejaswi, Veeram Reddy, A Latha, Arumugam Indira, and M Radhika. 2016. "Effectiveness of Leg Stretch Exercises on Fatigue among Patients Undergoing Haemodialysis." International Journal Of Applied Research 2(6): 74-76.
Zyga, Sofia, and Paul Sarafis. 2009. "Haemodialysis Adequacy Contemporary Trends." health Science Journal 3(4): 209-15. 